\title{
Characters of the leaf and stem morpho-anatomy of Alternanthera brasiliana (L.) O. Kuntze, Amaranthaceae
}

\author{
Márcia do Rocio Duarte ${ }^{1 *}$, Maria do Carmo Debur
}

'Laboratório de Farmacognosia, Departamento de Farmácia, Universidade Federal do Paraná

*Correspondence:

M. R. Duarte

Rua Pref. Lothário Meissner, 3400

Jardim Botânico

80210-170 - Curitiba - Brazil

E-mail: marciard@ufpr.br

\begin{abstract}
Alternanthera brasiliana (L.) O. Kuntze, Amaranthaceae is a Brazilian perennial herb employed as analgesic and antiinflammatory in the traditional medicine. This work has analysed the morpho-anatomy of the leaf and stem, in order to supply knowledge to the medicinal plant identification. The botanical material was fixed, freehand sectioned and stained according to usual microtechniques. The leaves are simple, entire, decussate, oval-lanceolate and purple, presenting uniseriate epidermis, pluricellular non-glandular trichomes coated by papillose cuticle, anomocytic and diacytic stomata on both surfaces; the mesophyll is dorsiventral, with collateral vascular bundles and druses. The stem, in secondary growth, has the dermal system similar to the leaf; the angular collenchyma alternates with the chlorenchyma; it occurs druses and a cambial variant, consisting of concentrical arcs of extra-cambia outside the first cambium and aligned vascular bundles in the pith.
\end{abstract}

Uniterms

- Alternanthera brasiliana

- Amaranthaceae

- Morpho-anatomy

- Medicinal plant

- Cambial variant

\section{INTRODUCTION}

Alternanthera brasiliana (L.) O. Kuntze, Amaranthaceae is a herb indigenous to Brazil (Macedo et al., 1999), described as perennial, prostrate and branchy, presenting a circular to polygonal stem in transection, long internodes and swollen nodes, at which opposite leaves attach. The inflorescence is cymes, composed of hermaphrodite, actinomorphous and monocyclic flowers (Furlan, 1984).

This species is named in Portuguese as doril, penicilina and perpétua, and is employed in the traditional medicine, mainly due to its analgesic and antiinflammatory properties attributable to the whole plant (Gonçalvez, Martins, 1998; Delaporte et al., 2001;
Lorenzi, Matos, 2002). Pharmacological essays have proven antinociceptive activities in mice (Macedo et al., 1999) and antiviral effects against herpes simplex (Lagrota et al., 1995). Moreover, to relation to other species of Alternanthera, studies have demonstrated antidiarrhoea (Zavala et al., 1998), immunostimulant and antitumor actions (Zirihi, Datte, Guede, 2001) of Alternanthera repens (L.) Link. and established the nutritional value of Alternanthera denticulata $\mathrm{R}$. Br. (Gunasekera, Bonila, 2001).

This work has aimed to analyse the leaf and stem morpho-anatomy of Alternanthera brasiliana (L.) O. Kuntze, Amaranthaceae in order to supply knowledge to the medicinal plant identification. 


\section{MATERIAL AND METHODS}

The botanical material was collected at the Horto de Plantas Medicinais, Departamento de Farmácia, Univer-

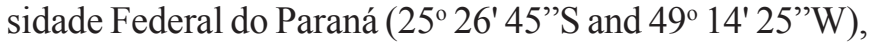
in August 2002. The dried material was identified and the voucher was registered under number MBM n ${ }^{\circ} 78158$ at the Museu Botânico Municipal de Curitiba.

Mature leaves, from the fourth node on, and stem fragments, collected $10 \mathrm{~cm}$ from the stem apex and progressively near the base, were fixed in FAA 70 (Johansen, 1940) and maintained in 70\% ethanol solution (Berlyn, Miksche, 1976). The examined foliar region was the petiole and the lower third of the blade and midrib. Transverse and longitudinal freehand sections were stained either with basic fuchsine/astra blue combination (Roeser, 1962) or with toluidine blue (O'Brien, Feder, McCully, 1965). Histochemical reactions were applied with hydrochloric phloroglucin to reveal lignified elements (Sass, 1951), iodine-iodide to starch (Berlyn, Miksche, 1976), Sudan IV to lipophilic substances (Foster, 1949) and ferric chloride to phenolic compounds (Johansen, 1940).

The results were registered by botanical illustration and photos obtained by means of the optical microscope Olympus BX40 and the control unit PM20.

\section{RESULTS}

A. brasiliana (Figure 1) has simple and entire leaves, with decussate phyllotaxy, oval-lanceolate shape, cuneate base, acute-acuminate apex and slightly wavy margin, measuring about $10 \mathrm{~cm}$ long and $4 \mathrm{~cm}$ wide. The foliar surface is membranous, moderately hairy and purple green on the adaxial side and purple on the abaxial.

The blade, in face view, has adaxial epidermal cells with polygonal contour (Figure 2) and sinuous abaxial cells (Figure 3 ) showing primary pit fields. In transection, the epidermis is uniseriate (Figure 6) and coated by a smooth and thin cuticle. Anomocytic and diacytic stomata are seen on both surfaces (Figures 2,3), although the latter type is predominant on the abaxial face. The inner and outer periclinal cell walls of the guard cells are thick and the cuticle forms ledges on the upper side. Stomata are even with the other epidermal cells or slightly raised above the surface (Figure 4).

Several pluricellular non-glandular trichomes, consisting of three to five cells ranked in one series and directed to the foliar apex, occur on both surfaces, although they are more frequent on the abaxial face. The trichome basal cells are nearly isodiametric, the other cells

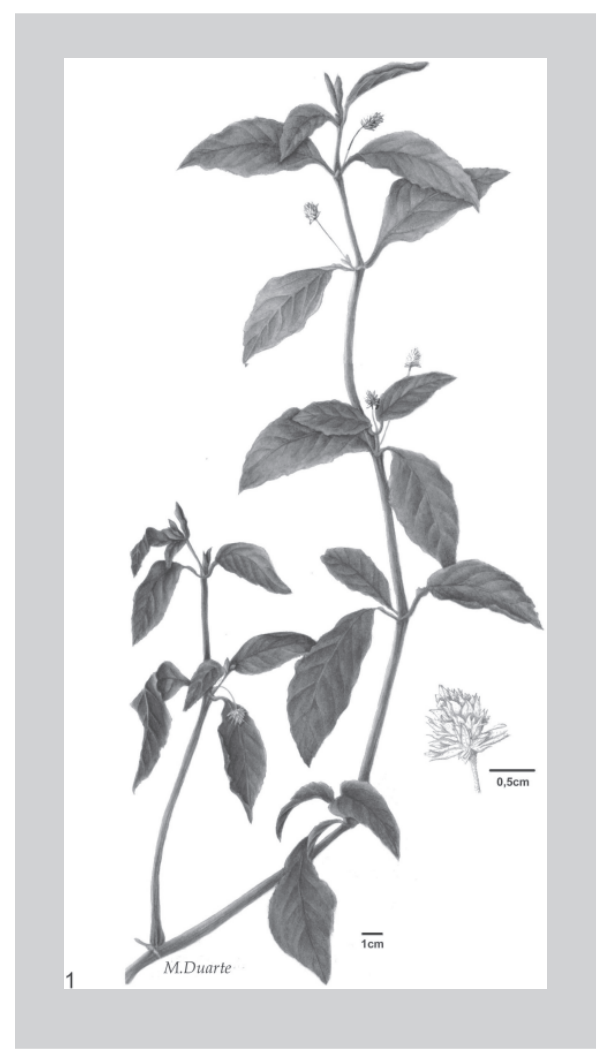

FIGURE 1 - Alternanthera brasiliana (L.) O. Kuntze, Amaranthaceae - apical branch aspect.

of the series are long and the apical is slender, all coated with a conspicuous papillose cuticle (Figure 5). In face view of the epidermis, the area of trichome detachments is distinguished.

The mesophyll reveals dorsiventral organisation, comprising one stratum of palisade parenchyma and about four layers of spongy parenchyma, the latter occupying $50-60 \%$ of the mesophyll (Figure 6). The chlorenchyma cell walls are impregnated by phenolic compounds and the parenchymatic cells near the midrib contain amiloplasts. Idioblasts having druses predominate in the palisade parenchyma. Minor collateral vascular bundles are embedded in the mesophyll and are enclosed by a sheath of large parenchymatic cells (Figure 7).

The midrib, in transverse section, shows a biconvex shape, prominent on the abaxial face (Figure 8). The epidermis has the same characteristics of the blade and, below it, the angular collenchyma is seen, formed by five layers on the adaxial side (Figure 10) and two layers on the opposite side. Collateral vascular bundles accompanied by thick-walled parenchymatic cells adjoining the phloem are embedded in the ground parenchyma. These vascular bundles vary in number and arrangement (Figures 8,9), from one crescent-shaped central vascular bundle, 


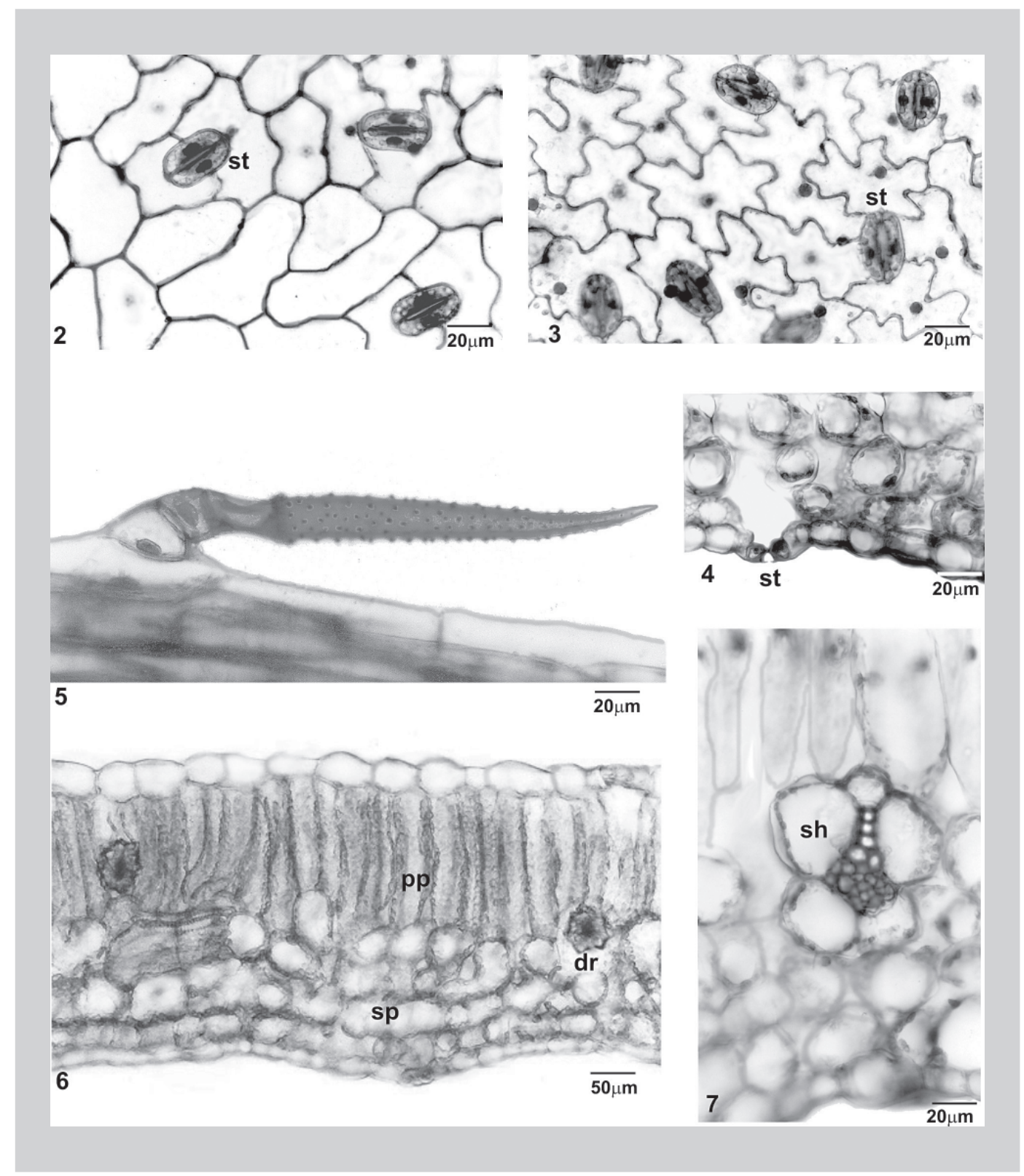

FIGURES 2 - 7-A. brasiliana - blade: 2, 3 - Face view of adaxial and abaxial epidermal cells, respectively; 4 - Slightly raised stomatum, in transection; 5 - Pluricellular non-glandular trichome coated by a papillose cuticle; 6 - Dorsiventral mesophyll in transection, showing idioblasts with druses; 7 - Transverse section of a minor collateral vascular bundle surrounded by a parenchymatic sheath. dr - druse, pp - palisade parenchyma, sh - sheath, sp - spongy parenchyma, st - stomatum.

associated with a smaller one near the adaxial face, to nine bundles distributed as a ring. A narrow cambial zone can be distinguished in the major bundles (Figure 11). Idioblasts containing druses are present in the ground parenchyma (Figure 9) and phenolic compounds are found in the phloem cell walls.

The petiole, in transverse section, has plain-convex contour (Figure 12). The epidermis is uniseriate (Figures
$13,14)$ and consists of polygonal cells in face view, few stomata and many non-glandular trichomes whose characteristics are similar to the leaf ones. A non-continuous ring of angular collenchyma occurs, consisting of two or three rows (Figure 13). Collateral vascular bundles (Figure 14), varying from four to eight, are distributed as an arc and embedded in the ground parenchyma, having caps of non-lignified and thick-walled cells next to the phloem. 


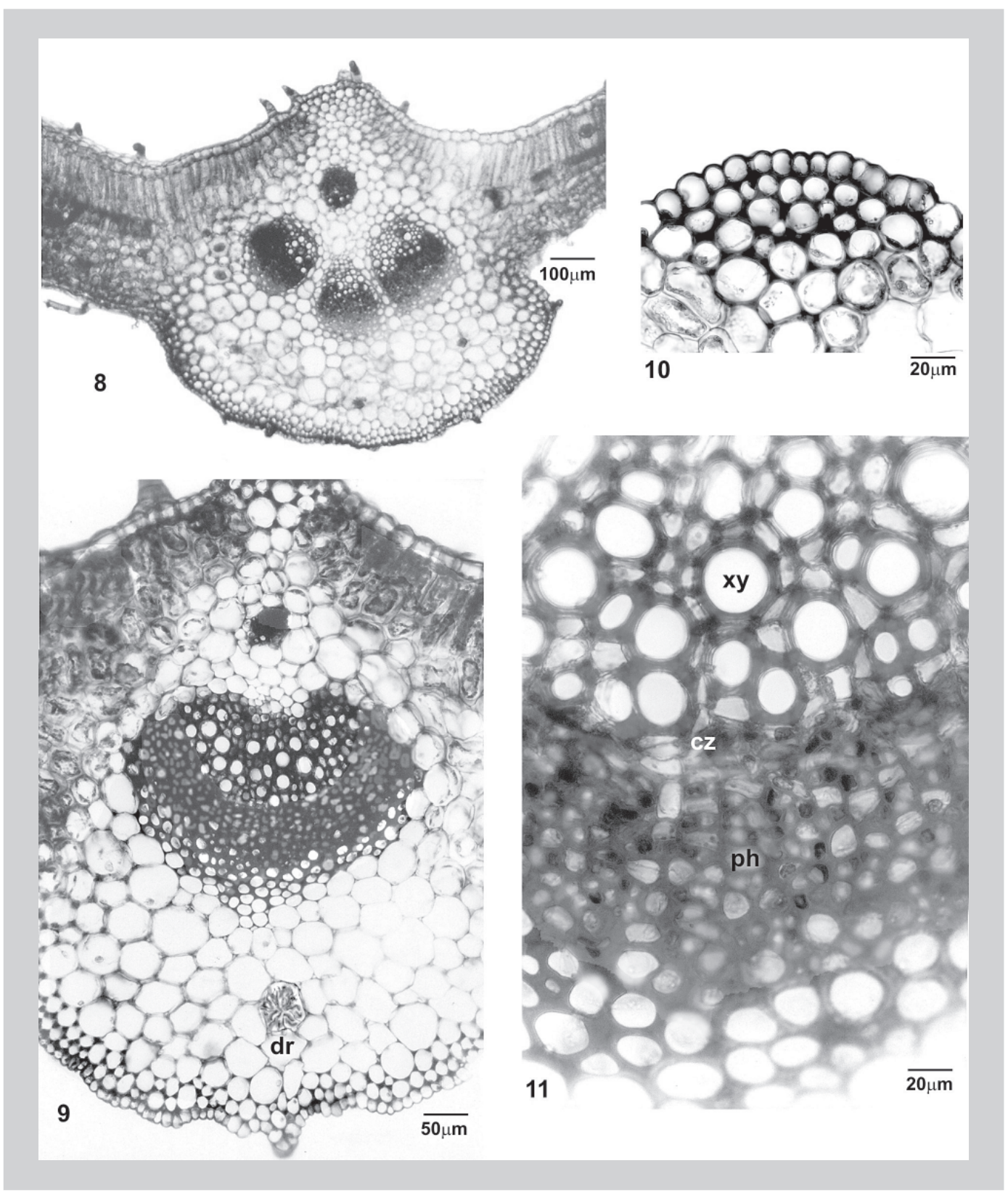

FIGURES 8 - 11 - A. brasiliana - midrib: 8, 9- Transverse sections of the lower third, exhibiting variable number of vascular bundles; 10 - Angular collenchyma below the adaxial epidermal face; 11 - Detail of the collateral vascular bundle. dr - druse, cz - cambial zone, ph - phloem, xy - xylem.

A cambial zone is seen between the phloem and the xylem. Idioblasts with druses and phloem cell walls impregnated by phenolic compounds are also observed.

The stem, in secondary growth, shows circular shape in transection. The epidermis is similar to the petiole. Strands of chlorenchyma and angular collenchyma alternate (Figure 15), and a parenchymatic sheath containing amiloplasts bounds the cortex internally. In the vascular cylinder, the first cambium forms phloem centrifugally and xylem centripetally (Figure 15). All the xylem cells are lignified, the tracheary elements exhibit an evident greater width and may be solitary or in radial multiples. Strands of perivascular fibres, in different stages of lignification, are next to the phloem (Figure 16). In the pith, two to six aligned vascular bundles are seen in a bipolar position (Figure 15). The minor vascular bundles are collateral and progressively become greater towards the centre. These central vascular bundles may be collateral or amphivasal and may have lignified cells in the centre of the phloem (Figure 17). Near the caulinar base, 


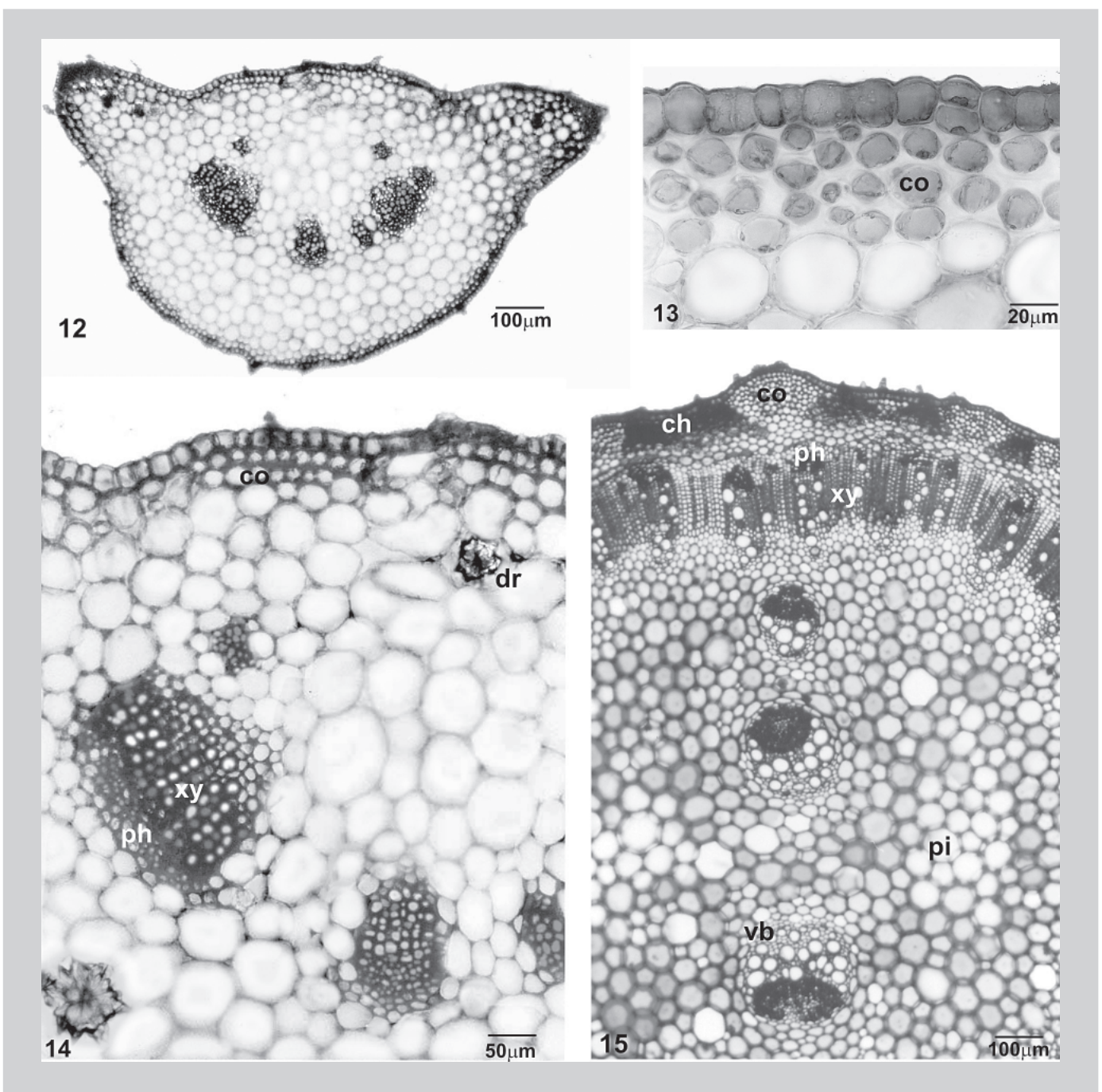

FIGURES 12 - 15-A. brasiliana: 12 - Petiole in transection; 13 - Angular collenchyma adjacent to the adaxial epidermis, in the petiole; 14 - Collateral vascular bundles embedded in the petiole ground parenchyma; 15 - Transverse section of the stem, near the apex. ch - chlorenchyma, co - collenchyma, dr - druse, ph - phloem, pi - pith, vb - vascular bundle, xy - xylem.

concentrical arcs of extra-cambia occur, each being formed externally to the precedent and differentiating phloem outside and xylem inside (Figures 18, 19). Idioblasts containing druses are found in the cortex and in the pith.

\section{DISCUSSION}

The leaf morphology of Alternanthera brasiliana (L.) O. Kuntze, Amaranthaceae is similar to the description by Takeda, Farago (2001), Delaporte et al. (2002) and Lorenzi, Matos (2002). In addition, according to these two authors, Alternanthera dentata (Moench) Stuchlik is so closely related to $A$. brasiliana, that some taxonomists consider it to be the same species. On the other hand, the leaves of $A$. brasiliana can be distinguished from Alternanthera tenella Colla and $A$. aquatica (Parode) Chodat as the former is oblong-lanceolate and sessile (Furlan, 1984) and the latter is oboval and has a long petiole (Bona, 1993).

The leaf is amphistomatic, following the Amaranthaceae pattern (Metcalfe, Chalk, 1950). Nevertheless, the anomocytic and diacytic stomatum occurrence has not been mentioned by Delaporte et al. (2002), who have described only the first type for $A$. brasiliana. Regarding Bona (1993), Alternanthera aquatica and A. philoxeroides (Mart.) Griseb. have anomocytic and predominantly diacytic stomata. 


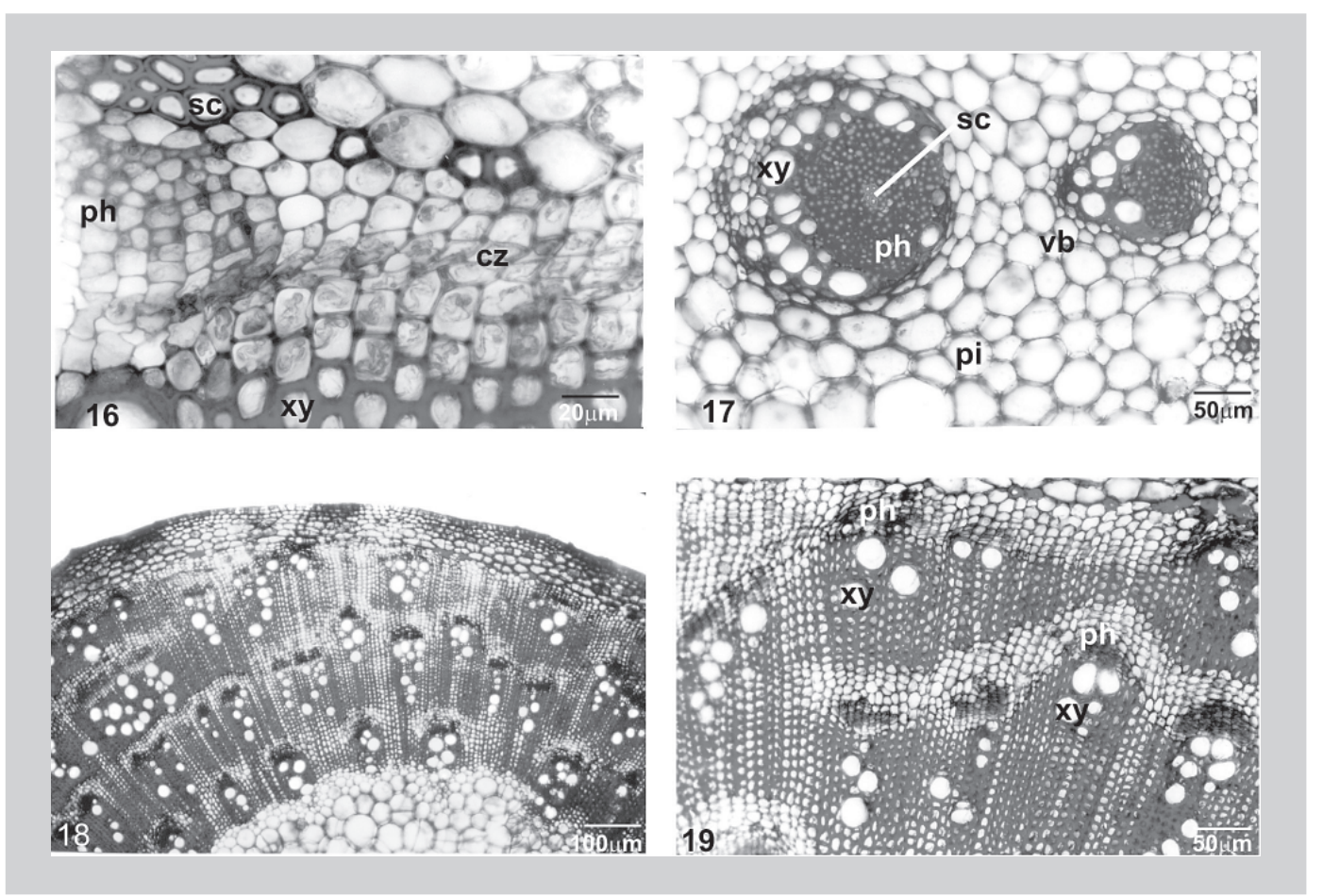

FIGURES 16 - 19-A. brasiliana - stem: 16 - Detail of the first cambium; 17 - Collateral vascular bundles associated with sclerenchyma in the pith; 18 - Transverse section, revealing the cambial variant organisation of stem near the base; 19 - Detail of the previous figure, indicating phloem and xylem. cz - cambial zone, ph - phloem, pi - pith, sc sclerenchyma, $\mathrm{vb}$ - vascular bundle, $\mathrm{xy}$ - xylem.

Although trichomes may have a characteristic form in a species and possess taxonomic value (Esau, 1977), the types vary in Amaranthaceae (Metcalfe, Chalk, 1950). The non-glandular trichome, coated by an evident papillose cuticle described in this work, has corresponded to the epidermal appendage cited by Delaporte et al. (2002). Comparing to other species, Alternanthera philoxeroides and $A$. aquatica show two different non-glandular trichomes (Bona, 1993), the longer being equivalent to the A. brasiliana type. Alternanthera stellata Uline et Bray presents a pluricellular non-glandular trichome which branches along an extended axis, named as dendritic (Metcalfe, Chalk, 1988).

Dorsiventral mesophyll is common in Amaranthaceae and druses are frequent in Achyranthes and Alternanthera (Metcalfe, Chalk, 1950). Various functions have been attributed to plant crystal idioblasts. Some evidences have pointed out to the ionic balance, which avoids the oxalate toxic accumulation, to the storage of calcium, to a protective function against herbivorous animals and even to mechanical support (Franceschi, Horner Jr., 1980).

Collateral vascular bundles, varying in number and arrangement in midrib and petiole, are mentioned for the family and Alternanthera. Despite Delaporte et al. (2002) having registered these characteristics in A. brasiliana leaf, they have cited sclerenchymatic caps in the midrib, differing from the present results. The thick-walled cells adjoining the phloem have not been considered lignified.

Concerning the stem organisation in secondary growth, the Amaranthaceae family has an abnormal development characterized by a sequence of concentrical extracambia, formed outside the original cambium (Esau, 1977). Different genus from this family, such as Achyranthes, Alternanthera, Amaranthus, Celosia, Gomphrena, Iresine and Pfaffia have been reported as presenting this cambial variant (Metcalfe, Chalk, 1950). Investigating the secondary growth in stem of Alternanthera pungens Kunth, A. sessilis (L.) R. Br., A. triandra Lam. and Achyranthes aspera L., Rajput, Rao (2000) have noted that the first cambium forms a complete cylinder and differentiates bidirectionally. When it ceases to divide, a new ring or a large arc of cambium develops external to the phloem. Similar findings have been mentioned in Alternanthera philoxeroides and A. aquatica (Bona, 1993; Bona, Morretes, 1997). This peculiar secondary growth is found in A. brasiliana, which shows extra-cambia and vascular bundles in the pith, some 
bundles presenting sclerenchyma. According to Metcalfe, Chalk (1988), medullary bundles may occur in Amaranthaceae, but they are not found in association with sclerenchyma. Moreover, their number and arrangement are not constant throughout the length of an individual plant (Metcalfe, Chalk, 1950). Rajput, Rao (2000) have not mentioned the presence of vascular bundles in the species of Amaranthaceae studied and Bona (1993) and Bona, Morretes (1997) have reported that Alternanthera philoxeroides and $A$. aquatica do not show vascular bundles in the medulla.

\section{RESUMO}

\section{Caracteres morfo-anatômicos da folha e do caule de Alternanthera brasiliana (L.) O. Kuntze, Amaranthaceae}

Alternanthera brasiliana (L.) O. Kuntze, Amaranthaceae, é herbácea perene de origem brasileira, empregada como analgésico e antiinflamatório na medicina tradicional. Este trabalho analisou a morfo-anatomia de folha e caule, a fim de fornecer subsídios à identificação da planta medicinal. O material foi fixado, seccionado à mão livre e corado de acordo com técnicas usuais. As folhas são simples, inteiras, decussadas, oval-lanceoladas e púrpuras, e apresentam epiderme unisseriada, tricomas tectores pluricelulares revestidos por cutícula papilosa, estômatos anomocíticos e diaciticos em ambas as faces; o mesofilo é dorsiventral, com feixes vasculares colaterais e drusas. O caule, em estrutura secundária, tem o sistema de revestimento similar ao da folha; o colênquima é angular em alternância com o clorênquima, ocorrem drusas e uma organização cambial variante, consistindo de arcos cambiais extranumerários concêntricos ao primeiro câmbio vascular e feixes vasculares dispostos linearmente na medula.

UNITERMOS: Alternanthera brasiliana. Amaranthaceae. Morfo-anatomia. Planta medicinal. Variante cambial.

\section{ACKNOWLEDGMENTS}

The authors are thankful to Gert Hatschbach from the Museu Botânico Municipal de Curitiba for the species taxonomic identification, and to $\mathrm{PIBIC} / \mathrm{CNPq}$.

\section{REFERENCES}

BERLYN, G. P.; MIKSCHE, J. P. Botanical microtechnique and cytochemistry. Ames: Iowa State University, 1976. $326 \mathrm{p}$.
BONA, C. Estudo morfo-anatomico comparativo dos órgãos vegetativos de Alternanthera philoxeroides (Mart.) Griseb. e A. aquatica (Parode) Chodat (Amaranthaceae). Curitiba, 1993. 196p. [Dissertação de Mestrado em Botânica. Setor de Ciências Biológicas, Universidade Federal do Paraná].

BONA, C.; MORRETES, B. L. Comparative stem anatomy of Alternanthera philoxeroides (Mart.) Griseb. and $A$. aquatica (Parodi) Chodat (Amaranthaceae). Arq.Biol.Tecnol., Curitiba, v. 40, n. 2, p. 285-96, 1997.

DELAPORTE, R. H.; SÁNCHEZ, M.G.; CUÉLLAR, C. A.; MELLO, J. C. P. Control de calidad y actividad antiinflamatoria de las drogas vegetales Alternanthera brasiliana (L.) Kuntze y Bouchea fluminensis (Vell.) Mold. Acta Farm.Bonaerense, La Plata, v. 20, n. 1, p. 3946, 2001.

DELAPORTE, R. H.; MILANEZE, M. A.; MELLO, J. C. P.; JACOMASSI, E. Estudo farmacognóstico das folhas de Alternanthera brasiliana (L.) Kuntze (Amaranthaceae). Acta Farm.Bonaerense, La Plata, v. 21, n. 3, p. 169-74, 2002.

ESAU, K. Anatomy of seed plants. 2. ed. New York: John Wiley, 1977. 550p.

FOSTER, A. S. Practical plant anatomy. 2.ed. Princeton: D.Van Nostrand, 1949. 228p.

FRANCESCHI, V. R.; HORNER JR., H. T. Calcium oxalate crystals in plants. Bot.Rev., Bronx, v. 46, n. 4, p. 361-427, 1980.

FURLAN, A. Flora fanerogâmica da reserva do Parque Estadual das Fontes do Ipiranga (São Paulo, Brasil). 31. Amaranthaceae. Hoehnea, São Paulo, v. 11, p. 72-6, 1984.

GONÇALVES, M. I. A.; MARTINS, D. T. O. Plantas medicinais usadas pela população do município de Santo Antônio de Leverger, Mato Grosso, Brasil. Rev.Bras.Farm., Rio de Janeiro, v. 79, n. 3/4, p. 56-61, 1998.

GUNASEKERA, L.; BONILA, J. Alligator weed: tasty vegetable in Australian backyards? J.Aquatic Plant Manag., Lehigh, v. 39, p. 17-20, 2001. 
JOHANSEN, D. A. Plant microtechnique. New York: McGraw-Hill, 1940. 523p.

LAGROTA, M. H. C.; WIGG, M. D.; MIRANDA, M. M. F. S.; SANTOS, M. G. M.; COSTA, S. S. Inhibition of herpes simplex virus replication by different extracts of Caryophyllales. Biomed.Lett., Cambridge, v. 51, n. 202, p. 127-35, 1995.

LORENZI, H.; MATOS, F. J. A. Plantas medicinais do Brasil: nativas e exóticas. São Paulo: Plantarum, 2002. $544 p$.

MACEDO, A. F.; BARBOSA, N. C.; ESQUIBEL, M. A.; SOUZA, M. M.; CECHINEL FILHO, V. Pharmacological and phytochemical studies of callus culture extracts from Alternanthera brasiliana. Pharmazie, Eschborn, v. 54, n. 10, p. 776-7, 1999.

METCALFE, C. R.; CHALK, L. Anatomy of the dicotyledons: leaves, stem, and wood in relation to taxonomy with notes on economic uses. Oxford: Clarendon, 1950. 1500p.

METCALFE, C. R.; CHALK, L. Anatomy of the dicotyledons. 2.ed. Oxford: Clarendon, 1988. v. 1, 276p.

O'BRIEN, T. P.; FEDER, N.; McCULLY, M. E. Polychromatic staining of plant cell walls by toluidine blue O. Protoplasma, Vienna, v. 59, n. 2, p. 368-73, 1965.
RAJPUT, K. S.; RAO, K. S. Secondary growth in the stem of some species of Alternanthera and Achyranthes aspera (Amaranthaceae). IAWA J., Leiden, v. 21, n. 4, p. 417-24, 2000.

ROESER, K. R. Die Nadel der SchwarzkieferMassenprodukt und Kunstwerk der Natur. Mikrokosmos, Stuttgart, v. 61, n. 2, p. 33-6, 1962.

SASS, J. E. Botanical microtechnique. 2. ed. Ames: Iowa State College, 1951.391p.

TAKEDA, I. J. M.; FARAGO, P. V. Vegetação do parque estadual de Vila Velha: guia de campo. Curitiba: Serzegraf, 2001.419p.

ZAVALA, M. A.; PÉRES, S.; PÉRES, C.; VARGAS, R.; PÉRES, R. M. Antidiarrhoeal activity of Waltheria americana, Commelina coelestis and Alternanthera repens. J.Ethnopharmacol., Limerick, v. 61, p. 41-7, 1998.

ZIRIHI, G. N.; DATTE, J. Y.; GUEDE, G. F. Activités immunostimulante et antitumorale de l'extrait aqueux d'Alternanthera repens (L.) Link. (Amaranthaceae). Rev.Méd.Pharmac.Afr., Eysines, v. 15, p. 59-66, 2001.

Recebido para publicação em 02 de junho de 2003. 